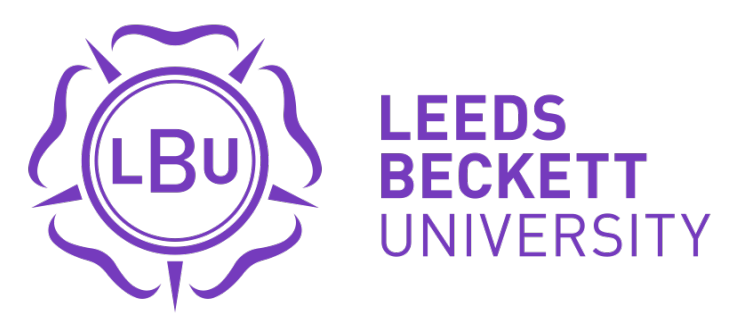

Citation:

Lu, Z and Wu, J and Liu, J (2020) Bank concentration and SME financing availability: The impact of promotion of financial inclusion in China. International Journal of Bank Marketing. ISSN 0265-2323 DOI: https://doi.org/10.1108/IJBM-01-2020-0007

Link to Leeds Beckett Repository record:

https://eprints.leedsbeckett.ac.uk/id/eprint/6902/

Document Version:

Article (Accepted Version)

The aim of the Leeds Beckett Repository is to provide open access to our research, as required by funder policies and permitted by publishers and copyright law.

The Leeds Beckett repository holds a wide range of publications, each of which has been checked for copyright and the relevant embargo period has been applied by the Research Services team.

We operate on a standard take-down policy. If you are the author or publisher of an output and you would like it removed from the repository, please contact us and we will investigate on a case-by-case basis.

Each thesis in the repository has been cleared where necessary by the author for third party copyright. If you would like a thesis to be removed from the repository or believe there is an issue with copyright, please contact us on openaccess@leedsbeckett.ac.uk and we will investigate on a case-by-case basis. 


\title{
Bank concentration and SME financing availability: The impact of promotion of financial inclusion in China
}

\begin{abstract}
Purpose - The promotion of financial inclusion can disturb the composition of traditional bank concentration and change the relationship between bank concentration and the availability of SME financing. This paper concentrates on a less frequently explored area of research by examining the relationships between bank concentration, financial inclusion, and SME financing availability, respectively, and the interaction between bank concentration and financial inclusion after the implementation of a financial inclusion strategy in China.
\end{abstract}

Design/methodology/approach - Using firm-level data from 1,509 listed SMEs in China from 2007 to 2017 and applying rigorous analyses, we identify how bank concentration affects SME financing availability under the promotion of financial inclusion and also the mechanisms involved.

Findings - We find that bank concentration and financial inclusion respectively have positive impacts on the credit available to listed SMEs, indicating that the promotion of financial inclusion in China has reached a new high watermark. The positive impact of bank concentration is reduced when the level of financial inclusion is high. Conversely, a higher level of financial inclusion favours SME credit availability at only a low degree of bank concentration. Our findings suggest that financial inclusion has a substitution effect on bank concentration and has enabled us to add new interpretations to relevant theories, namely, the Market Power and Information Theories respectively.

Originality/value - This study provides new insights into the relationship between bank concentration and SME finance availability under the promotion of financial inclusion. 
Keywords: bank concentration; financial inclusion; SME financing availability; FinTech; China.

Paper type: Research paper 


\section{Introduction}

Financial inclusion (or inclusive finance) is the conceptual opposite of Financial Exclusion (Koku, 2015). Financial inclusion describes a social phenomenon whereby a group of vulnerable people, including individuals (e.g. farmers) and firms (e.g. small and medium-sized enterprises - SMEs), are at a disadvantage when seeking to access or utilise financial services and products provided by mainstream banks and financial institutions. In 2005, the United Nations (U.N.) proposed the establishment of a unified global system of financial inclusion to counter financial inequality. China responded quickly to the U.N. initiative and initiated banking sector reform, including reducing the banking market admittance threshold.

As a result of financial inclusion promotion in China, many smaller and private financial institutions were able to gain access to the banking market, which had formerly been traditionally dominated by large state-owned banks, thus fundamentally changing the degree of bank concentration ${ }^{1}$. In the literature, there are two contradictory theories explaining the relationship between bank concentration and SME debt financing. On one hand, the Market Power Theory (Klein, 1971) asserts that the monopolistic power held by large banks in a concentrated bank market would reduce competition in the sector. Consequently, SMEs would be discriminated against when seeking access to bank loans because most of them are not publicly listed, lack collateral in the form of assets, and generally do not have credit ratings (Berger and Udell, 1998, 2002; Han et al., 2017; Liu et al., 2018). On the other hand, Petersen and Rajan $(1994,1995)$ challenge the Market Power Theory by providing an alternative - the Information Theory. They argue that having market power enables banks to maintain stable relationships with clients without charging them higher loan interest rates because the long-

\footnotetext{
${ }^{1}$ Bank concentration is usually measured by the market share of the largest banks (e.g., top 3 or 5 banks) (Beck et al., 2005b).
} 
term relationship helps reduce information asymmetry and operational costs. SMEs are therefore beneficial to bank concentration (Ryan et al., 2014).

We argue that the preconditions for these two theories could be significantly changed when there are promotion and implementation of financial inclusion in the banking market. Therefore, the traditional views of Market Power and Information theories might invite novel or supplementary interpretations. For example, many newcomers to the lending market are diversified financial institutions and FinTech (financial technology) firms. They are smaller, less bureaucratic, flexible in providing new financial products and lending services, and particularly capable and robust in applying new lending technologies. Such features would make these lenders more likely to advance funds to SMEs. Thus, when they compete with large banks in the lending market, the structure of this market could be significantly altered by the innovative financial products and convenient lending services encouraged by the promotion of financial inclusion. Consequently, there is an urgent need for research evidence to facilitate scholarly debate and inspire theoretical contributions.

Since 15 years have passed since the promotion of financial inclusion in China, it is opportune and interesting to determine how new bank concentration and SME financing availability have been influenced by financial inclusion. A lack of evidence in the existing literature suggests that such research is timely and relevant. This paper therefore aims to illuminate this issue and find answers to three research questions: (1) whether, and to what extent, new bank concentration has improved the availability of SME financing since the promotion of financial inclusion; (2) how, and to what extent, financial inclusion has helped SMEs to access finance products and services; and (3) what is the relationship between bank concentration and financial inclusion?

This study collects data from 1,509 listed SMEs in 30 provinces of China from 2007 to 2017 
and conducts rigorous analyses. Our findings confirm that, although there are imbalances in regions, new bank concentration in China has been dramatically improved in the sense of benefiting SME financing by means of financial inclusion promotion; that financial inclusion, measured by the availability, usability, and utility of financial services is also conducive to more than half of SMEs gaining access to banking services; and that financial inclusion becomes a vital substitute for bank concentration. We also find and report several other interesting findings, which have a number of meaningful policy implications for the Chinese government, as well as for similar transitional economies.

The rest of the paper is structured as follows: Section 2 states the theoretical arguments on bank concentration and SME financing, and financial inclusion and SME financing to establish testable research hypotheses. Section 3 introduces data, variables, and analytical models. Section 4 presents the firm level and regional level data analysis results. Section 5 concludes, highlights the contributions and policy implications, and discusses limitations.

\section{Theoretical argument and hypothesis development}

Two contradictory theories explain the relationship between bank market concentration and SME debt financing. Market Power Theory (Klein, 1971) suggests that when bank concentration occurs, bank market power increases and competition in the industry decreases because high concentration gives large banks monopolistic power in a region or country. Bank concentration reduces market efficiency, resulting in banks supplying fewer loans at higher interest rates to SMEs (Degryse and Ongena, 2005). Moreover, large banks are more likely to use income-gearing approaches when evaluating firms' loan repayment ability; however, most SMEs are in an inferior position due to lack of collateral assets and credit ratings (Berger and Udell, 1998, 2002; Wu et al., 2008). Furthermore, bank concentration restricts SME financing 
particularly severely in emerging countries, where the banking sector is dominated by large and state-owned banks that have bureaucratic structures and low operating efficiency (Beck et al., 2004, 2005a). In short, bank market concentration is not beneficial to SME financing.

Petersen and Rajan (1994, 1995), however, propose a contrasting interpretation; namely, Information Theory. This argues that having market power secures banks a superposition, that there is no need for banks to charge premium loan interest rates but to motivate them in developing a long-run relationship with SMEs to overcome information opacity and reduce lending risks. In other words, private information acquisition is more easily internalised by lenders in a concentrated market. Thus, market power will benefit both banks and SMEs if they establish a stable relationship to lower information asymmetry and agency costs (Ryan et al., 2014). To be specific, bank concentration can help minimise the problems of adverse selection, moral hazard, and hold-up caused by information asymmetry between lenders (banks) and borrowers (SMEs) (Beck and Demirgüç-Kunt, 2006, 2008; Beck et al., 2004; Binks et al., 2006). Therefore, bank market concentration is helpful for SME financing.

The debate above emphasises that the relationship between bank concentration and SME debt finance is a multi-faceted issue which should not be viewed in isolation. From the arguments adduced, we understand the key focuses for Market Power Theory relate to the percentage of large banks in the banking market, their monopolistic power, and diversity in the sector. Whereas, in respect of Information Theory, the critical issue is the reduction of operational costs through effective communication with clients to reduce information asymmetry. However, when other factors are considered, either Market Power or Information Theory might need to be changed. We argue that the promotion of financial inclusion in China is an important stimulant that is altering the structure and services in the banking sector, which can fundamentally influence the lending environment of SMEs. Therefore, the findings of Market Power Theory and Information Theory could be modified. We explain our argument 
from two perspectives: changes in the banking market structure and banking services as a result of financial inclusion promotion in China, and how these changes have impacted on SMEs' ability to access sources of finance.

Changes in the banking market structure since promoting financial inclusion in China and their impact on the availability of SME financing

China had a state-owned mono-banking system before initiating economic reform in 1978, comprising of a state-led, two-tiered banking system from 1979 to 1993 that was dominated by five large, state-owned commercial banks ${ }^{2}$. Between 1993 and 2005, despite market-orientated reform of the banking system being implemented, such changes had not significantly increased the availability of financing channels to private SMEs and resulted in the closure of a large number of small banks. Bank lending therefore continued to favour state-owned enterprises (SOEs) and government-guaranteed infrastructure projects.

Since 2005, following the U.N.'s promotion of financial inclusion, a fundamental consolidation in the Chinese banking sector has been implemented by the financial authorities ${ }^{3}$ to make the financial industry more inclusive. These reforms, consisting of a series of strategies, policies, and regulations, have led to fundamental changes in the banking market structure, financial infrastructure, and lending technology. Consequently, the proportion of the total assets of large commercial banks in the industry reduced from 56\% in 2005 to $37 \%$ in 2016 (CBRC, 2016), and a diversified banking structure has been rapidly established. Table 1 provides details of financial service providers, their relationships with financial inclusion and

\footnotetext{
2 Industrial and Commercial Bank of China, Agricultural Bank of China, Bank of China, China Construction Bank, and Bank of Communications

${ }^{3}$ People's Bank of China - PBOC, China Banking and Insurance Regulatory Commission - CBIRC, formerly CBRC and CBIC , the China Securities Regulatory Commission - CSRC, and the Ministry of Finance -MOF
} 
their proportionate share of the lending market by the end of $2017^{4}$. From Table 1, we can see that although the large five state-owned commercial banks still play an important role, their dominant position has been challenged by many other smaller financial service providers offering loan services to SMEs. The diversity of the banking market would certainly increase pressure on large banks to change their strategies to compete with their smaller competitors ( $\mathrm{Li}$ et al., 2020). Large banks are more advanced in terms of financial and human resources, operational and management systems, and risk control compared to their smaller counterparts. Once large banks compete actively in the lending market, this new bank concentration is particularly helpful in helping to alleviate the difficulties SMEs face when seeking finance. Thus, the Market Power Theory can be restated when applying this new institutional context.

[Insert Table 1 here]

Based on this rationale, our first hypothesis can be presented as follows:

H1: Under the promotion of financial inclusion in China, bank concentration has positive effects on SME debt financing.

Changes in banking services since the promotion of financial inclusion in China and their impacts on SME financing availability

Accessibility, diversity, and appropriate products are essential elements for promoting the success of financial inclusion; however, the sustainability of such a system is challenging because of the substantial operational costs entailed. Reducing the asymmetry of information

\footnotetext{
${ }^{4}$ It is worth noting that Table 1 excludes some new financial service providers such as nonbank digital payment providers, internet-based microlending, internet-based fund management, and internet equity-based crowdfunding because of data unavailable.
} 
between banks and financial institutions and SMEs is, therefore, an effective way of reducing high operational costs, which is also a fundamental precept of Information Theory.

China's promotion of financial inclusion in the last 15 years has significantly changed the landscape of the banking industry. This achievement can be explained with reference to three factors: legislation, policy/regulation, and institutions. First, important legislative steps comprise of: (1) the $3^{\text {rd }}$ Plenary Session of the $18^{\text {th }}$ Central Committee of the Communist Party of China published the official financial inclusion document in 2013; (2) the State Council issued the 'Plan for the Development of Financial Inclusion (2016-2020)' in 2015; and (3) CBRC issued the 'Implementation Plan for Establishing Financial Inclusion Division in Large and Medium-sized Commercial Banks’ in 2017.

Second, at the policy/regulation level, a series of fiscal, monetary, credit, and tax policies and regulations have been put in place to encourage the diversification of financial service providers and products. These policies include, for example, facilitating local governments' risk compensation funds to SME lending; establishing government-owned guarantee companies for SMEs; exempting VAT and stamp tax on small loans; reducing the reserve ratio for banks (i.e., meeting the requirements for prudent operation and for holding a certain proportion of loans to SMEs); subsidising the interest on loans to start-up and innovative firms; differentiating calculation and assessment of loan-to-deposit (LTD) ratios and nonperformance loan ratios for SME loans; and making exclusively financial bonds available for SMEs (World Bank, 2013, 2014).

Third, at the organisational level, the revolution of digital finance technology enables financial service providers to utilise and maintain cost-effective digital finance technology, which can significantly and effectively leverage operational processes and reduce associated costs. For instance, the use of digital borrowing platforms enables SMEs to gain swift access 
to diverse, innovative, and suitable financial products at affordable and competitive prices, reducing reliance on physical bank branches. Digital lending and payments systems enable financial service providers to reach a broader range of borrowers' groups; to design tailored financial products more easily; make transactions promptly; and obtain and store customer information more accurately and efficiently. The rise of competition from many new FinTech companies also forces traditional banks to adopt digital approaches themselves in order to compete, and to serve previously ignored borrowing groups such as SMEs (CGAP, 2015).

It follows from our discussion that the promotion of financial inclusion in China has significantly boosted SME debt availabilities because of the diversification of lending providers, suitable lending products, and the development of accessible lending services. Thus, we state our second testable hypothesis as follows:

H2: Financial inclusion in China has had positive effects on SME debt financing.

In the next section, we introduce our sample, variable measurements and analytical models.

\section{Data and model description}

Sample

We target all listed companies in the new OTC market ${ }^{5}$ and the $\mathrm{GEM}^{6}$ in China from 2007 to 2017, covering the period of financial inclusion promotion. The justification for starting from 2007 is that, in 2006, the Ministry of Finance of China issued new accounting standards which introduced fair value in accounting information. As such, there is a significant difference in financial information disclosure for listed firms before and after 2006, especially in terms of

\footnotetext{
${ }^{5}$ Established in 2006 and compared to China's the main and second board markets, the new third board market attracts more start-up firms that need financing but having lower listing requirements (Li et al., 2015).

${ }^{6}$ Growth Enterprise Market (GEM) is a board in the Stock Exchange of Shenzhen for growth enterprises that do not meet the requirements of profitability or track record in the main board of the exchange.
} 
asset and liability measurements. Three criteria are applied in the process of finalising sample inclusion: first, we exclude all financial and utility firms to ensure financial information comparability in the sample; second, due to some abnormal and incomplete macroeconomic and financial institution information about the province of Tibet, the latter is excluded; and third, all firm-year observations with missing values are also excluded. Our final sample comprises 9978 firm-year observations from 1509 listed firms.

The data used in the study is collected from three sources: (1) All province related data is obtained from the China Statistical Yearbook, issued by the National Bureau of Statistics of China. Provincial data generally describe different characteristics of all provinces in China, including macroeconomic information and numbers of the legal person undertaking economic activity. (2) Asset information of financial institutions is collected from the Regional Financial Operation Reports published by PBOC covering the same period (2006-2016). (3) Information about firms' access finance is collected from individual firms' financial statements included in the China Stock Market \& Accounting Research (CSMAR) database. The database also discloses firms' statutory information, such as primary and equity information, which can provide additional information for our sample selection.

\section{Dependent variables}

Two dependent variables are used to represent SME financing available in the study. First, FINANCE PROBABILITY is used as an indicator variable to examine the probability of a firm's access to finance: it equals one when a firm has a loan and zero otherwise. Second, as a supplement to FINANCE PROBABILITY, a dependent measure of the bank credit financing scale, FINANCE SIZE is calculated by using bank loan/total assets.

\section{Measuring bank concentration}


Following Love and Pería (2014), we construct two commonly used measures of bank concentration. First, CONCENTRATION-5 is the regional market power of the top five banks, which equals the share of bank assets held by the five largest banks in each province. Second, we use the Herfindahl index to measure bank concentration (CONCENTRATION-H), which is equal to the sum of the squared asset shares of each type of bank. In both cases, higher values indicate a higher concentration. We use 1-year lagged bank concentration to analyse the impact on SME finance.

\section{Measuring financial inclusion}

An index is used to measure Finance Inclusion, which is the measurement of the quality of financial services provided by regional financial institutions and the scope of their customers. The core value of the index represents the service coverage provided by financial institutions, i.e., the impact of financial services on social groups/enterprises. Considering that the purposes of the development of the financial inclusion system in China are to increase coverage, usability, and satisfaction of financial services, the calculation of the index following Zhou et al. (2018) includes three dimensions: availability, usability and utility of financial services. First, we consider two levels of information to capture the availability of financial services: customer group scope of services of financial institutions and customer group scope of services of financial personnel. Second, we add three variables into the usability of financial services: residents' use of financial services, insurance density, and insurance penetration. Third, we consider two factors of the utility of financial services: utility embodied in deposit and other financial services, and utility incorporated in lending and other financial services. The specific indexes of financial inclusion are represented in Table 2.

[Insert Table 2 here] 
Referring to the calculation method for the index of financial inclusion proposed by Sarma and Pais (2011), our index calculation steps can be explained as follows:

(1) Standardised processing of various dimension indexes: to more intuitively display the differences among the dimension indexes at the regional level and avoid the impact of indexes in the order of magnitudes, standardised processing is conducted for every dimension index, which involves the processing of positive indexes and processing of negative indexes:

$$
x_{j k t}^{\prime}=\frac{x_{j k t}-\min \left\{x_{k t}\right\}}{\max \left\{x_{k t}\right\}-\min \left\{x_{k t}\right\}}
$$

$x_{j k t}$ represents the $k$ index value of $j$ province in year $t, x_{j k t}^{\prime}$ refers to the value after $x_{i k t}$ goes through standardised processing, $\max \left\{x_{k t}\right\}$ is the maximum value of the $k$ index in year $t$, and $\min \left\{x_{k t}\right\}$ stands for the minimum value of the $k$ index in year $t$.

(2) Calculation of the weight of each dimension: to measure the importance of different dimensions in the inclusive finance indexes, the coefficient of variation method was used to calculate the weight of each dimension, and the calculation formula is as follows:

$$
\begin{gathered}
v_{k t}=\frac{S_{k t}}{A_{k t}} \\
w_{k t}=\frac{v_{k t}}{\sum_{k=1}^{7} v_{k t}}
\end{gathered}
$$


where $V_{k t}$ represents the coefficient of variation of the $k$ index in year $t, S_{k t}$ represents the standard deviation of the $k$ index in year $t, A_{k t}$ represents the mean value of the $k$ index in year $t$, and $W_{k t}$ stands for the weight of the $k$ index in year $t$.

(3) Calculation of the measuring values for all dimensions: to show the characteristics of the measuring values for all dimensions more intuitively, the index value that underwent standardised processing in each region is multiplied by the weight of each dimension, thereby obtaining the measuring value $E_{k t}$ for each dimension:

$$
E_{k t}=w_{k t} \times x_{j k t}^{\prime}
$$

(4) Calculation of the index of inclusive finance: This study uses the calculation method for human development indexes to calculate the index of financial inclusion, correspondingly exhibiting service quality and customer group scope of financial institutions at the macro level.

The calculation formula is as follows:

$$
I N C L U S I O N=1-\frac{\sqrt{\sum_{k=1}^{7}\left(W_{k t}-E_{k t}\right)^{2}}}{\sqrt{\sum_{k=1}^{7} W_{k t}^{2}}}
$$

where INCLUSION represents the index of inclusive finance of $j$ province in year $t, 0 \leq$ INCLUSION $\leq 1$, and we use 1-year lagged INCLUSION to analyse the loan effect on SME finance $^{7}$. The higher the index of inclusive finance is, the better the environment for the development of financial inclusion in the region.

\footnotetext{
${ }^{7}$ Given that the bank lending decision are most likely based on firm financial information and macroeconomic situation from the previous year, our independent variables and control variables are all 1-year lagged.
} 


\section{Control variables}

There is strong evidence that firm characteristics and macroeconomic conditions can affect firms' access to finance, and we thus control for these factors as 1-year lagged (see GarcíaTeruel and Martínez-Solano, 2008; Rice and Strahan, 2010; Leon, 2015). Regarding firm characteristics, we include the size of the firm (Log SALES), which is the logarithm of lagged sales. Our specification also consists of the firm's inventory status (INVENTORY), which equals the value of inventory to total assets. We also control for firm sale growth rate (GROWTH), firm return on assets (ROA), and firm age (log FIRM AGE). Last, we control for the type of ownership by including a dummy variable that is equal to one when part (or all) of the firm is owned by the State (STATE) to reflect a historical and cultural phenomenon in China: SMEs are often more difficult to obtain loans from state-owned banks.

Furthermore, the macroeconomic conditions are controlled by regional gross domestic product (log GDP) and the GDP growth rate (GDP GROWTH). Also, we control for the degree of government intervention using the proportion of the government's financial expenditure on regional GDP (GOVERNMENT INTERVENTION) to capture another unique feature in China (Du et al., 2017).

A summary of basic statistics for the firm and province-level variables is reported in Table 3. Table 3 shows that almost seven out of $10(68.6 \%)$ firms in our sample obtain financing from banks, and the other $30 \%$ firms do not get bank loans. The average bank credit financing scale is $13 \%$ of total assets. In terms of financial inclusion, the average figure (0.618) is also encouraging. However, there is substantial variation among provinces as the reading is between 0.17 and 0.998 . The average share held by the top 5 banks in regions reaches near half $(43.3 \%)$ 
with the lowest $19.8 \%$, whereas the highest is $62.1 \%$. The Herfindahl index varies between 0.106 and 0.707 , with an average of 0.276 .

[Insert Table 3 here]

\section{Analytical model}

In this paper, we assume bank concentration has different effects on firms' financing availability dependent on the degree of financial inclusion. We thus estimate using an econometric model in the following form:

$$
\begin{gathered}
\text { Access to } \text { finance }_{i j t}=\beta_{0}+\beta_{1} \text { CONCENTRATION }_{j t-1}+\beta_{2} \text { INCLUSION }_{j t-1} \\
+\beta_{3} \text { CONCENTRATION }_{j t-1} \times \text { INCLUSION }_{j t-1} \\
+\beta_{4} \text { Control variables }+\varepsilon
\end{gathered}
$$

where firms' access to finance is measured as FINANCE PROBABILITY and FINANCE SIZE, in the baseline analysis, for the Probit and Ordinary Least Squares (OLS) models, respectively. Control variables are a set of time-varying firm-level characteristics and provincial macroeconomic conditions, as well as industry and year dummies.

Equation (6) tests the effect of bank concentration on a firm's access to finance. In addition, our model also includes the interaction term of bank concentration with financial inclusion (CONCENTRATION $\times$ INCLUSION). This interaction variable is intended to capture how and to what extent financial inclusion affects the impact of banking market structure on a firm's access to finance.

Additionally, some SMEs which do not have bank loans might lack them because of other reasons (e.g. they do not need bank loans); in this case, Probit or OLS models used to analyse 
FINANCE PROBABILITY and FINANCE SIZE may cause estimation bias due to the problem of sample selection (Heckman, 1979). To eliminate the influence of the sample selection, we employ Heckman's selection models and analyse FINANCE PROBABILITY and FINANCE SIZE in a unified model in robustness checks. In line with the principle of Heckman's selection models, we first use the Probit model to estimate the Equation of FINANCE PROBABILITY and obtain the estimated value of the probability $\lambda$ for each SME, and then add $\lambda$ as a control variable in the Equation of FINANCE SIZE to eliminate the influence of sample selection.

The analytical results are presented in the next section. It includes two subsections. In the first subsection (4.1), we test the two hypotheses and the issues surrounded based on the firmlevel data; in the second subsection (4.2), we look at how regional credit environment plays a part in the relationship between bank concentration/financial inclusion and SME finance availabilities.

\section{Results}

4.1.The impacts of bank concertation and financial inclusion on SME's debt financing

\section{Baseline regression}

The estimation of Equation (6) is reported in Table 4. Columns (1) and (3) of Table 4 are estimated using Probit and OLS estimators with the sector and year dummies, respectively. In Table 4, we also consider the potential endogeneity of firm-level variables that may stem from time-invariant confounding factors. To address this, we account for a firm fixed effect and the results reported in columns (2) and (4).

[Insert Table 4 here] 
First, to achieve our first research objective, we are primarily interested in assessing how and to what extent the new bank concentration under the promotion of financial inclusion impacts the listed SME financing availability. From columns (1) and (3) of Table 4, we observe that the coefficients of CONCENTRATION are positive and statistically significant at the $1 \%$ level, suggesting that Hypothesis 1 is confirmed. The finding supports that under the promotion of financial inclusion in China, bank concentration has positively affected the sample SME finance probability and finance size. When we further consider the influence of financial inclusion by using an interaction variable (CONCENTRATION $x$ INCLUSION), the result is significantly negative, indicating that the promotion of financial inclusion has significantly decreased the effect of bank concentration on SME financing. Additionally, a threshold measure is added for a more accurate estimation on the impact. As indicated in the second row from the bottom of Table 4, when financial inclusion is higher than 0.90 (or 0.46), bank concentration would have a negative effect on firm finance probability (or finance size). The finding demonstrates that SME credit availability from bank concentration (new structure of banking market) in China has been dynamically improved in the environment of financial inclusion.

Second, in relation to the second objective, we are equally interested in evaluating the effect of financial inclusion on the listed SME financing availability. We observe that the coefficients of INCLUSION are positively and statistically significant, which confirms our Hypothesis 2 and indicates that financial inclusion in China plays a vital role in helping SME financing. Besides, the interaction variable (CONCENTRATION x INCLUSION) with significantly negative value suggests that the impact of financial inclusion on listed SME finance availability is dampened by bank concentration, meaning the role of financial inclusion would be reduced in a highly concentrated bank market; in other words, financial inclusion has partially 
substituted for bank concentration. Similarly, after adding a threshold measure, the last row of Table 4 shows that financial inclusion has a positive effect on firm finance probability (or finance size) for the levels of bank concentration lower than $37 \%$ (or $31 \%$ ).

Third, we want to know if any kind of SMEs benefits more than others in obtaining debt finance. The firm-level control variables suggest that state-owned firms (STATE) and larger companies (Log SALES) have a better position to access bank finance than other types of firms which have better financial performance (ROA). The result indicates that smaller and private firms are still in a disadvantaged position in obtaining financial resources compared to their state-owned and large counterparts, even though financial inclusion has made substantial progress.

Fourth, we also want to see if regional economic development and government intervention contribute to SME finance availability. Turning to the provincial control variables, column (1) suggests that a regional level of development (GDP GROWTH) is not a key factor for firm finance probability. This result perhaps can be explained by the fact that most policies and regulations relating to banking finance are mainly set up at the national rather than local level, and therefore local economic development is irrelevant. Another finding is that government intervention (GOVERNMENT INTERVENTION) is negatively correlated with firm finance probability and finance size at a 1\% statistically significant level. This result, perhaps, should be understood as a reflection of the extent to which the government still controls state-owned and large banks.

Finally, the results in columns (2) and (4) of Table 4 from the firmly fixed-effect model suggest that accounting for firm-level time-unvarying unobservable heterogeneity does not alter the conclusions of our baseline estimation. 


\section{Robustness checks}

We consider robustness checks for baseline analysis from three perspectives: (1) the replacement of measures of financial inclusion, bank concentration and control variables; (2) the estimated model; and (3) sample dependence. The results are presented in Table 5.

(1) Alternative measures of bank concentration, financial inclusion, and control variables.

Table 5 re-estimates the baseline estimation using alternative measures of bank concentration, financial inclusion and control variables. First, we replace measuring bank concentration by the Herfindahl index of assets in all types of banks (CONCENTRATION-H). Also, according to Goldsmith (1969), the financial interrelations ratio can be used to measure a region's financial development level and we, therefore, presume that the level of financial development should be related to the level of financial inclusion. Referring to the relevant studies conducted by Rajan and Zingales (1998), and Acharya and Xu (2017) in financial development, we replace the measure of financial inclusion by total regional financing in the GDP ratio (INCLUSION-DL), which is calculated as (Stock Market Capitalisation + Bond Market Capitalisation + Bank Credit)/ (GDP). The results in Table 5 (see columns (1) and (2)) convert unchanged meanings with that in the baseline analysis. Furthermore, we aggregate the firmlevel controls at the province-year level, referring to Harrison et al. (2014). We replace the firm-level variables with the average values for the size, growth, performance, inventory, and age of firms in the same province and with the share of firms in the province that are state-

owned. Again, the regression results in columns (3) and (4) in Table 5 show the same conclusion with that of Table 4.

[Insert Table 5 here]

(2) Heckman's selection model 
To address the potential bias from the problem of sample selection, we employ Heckman's selection model. We include two exclusion variables that probably affect finance probability in the selection equation, and the ratio of liability to the asset in the last year, $\mathrm{LEV}_{\mathrm{it}-1}$, which represents the real financial leverage of the firm. We also include the ratio of cash to assets in the previous year, $\mathrm{CASH}_{\text {it- } 1}$ to reflect the internal capital available for investment in the firm.

We re-estimate our baseline estimation using Heckman's selection model and present the results in Table 6 . The findings suggest that the L.R. tests are statistically significant at a $1 \%$ level, indicating we should apply the Heckman's selection model to test the relationship between bank concentration and SME financing availability. The exclusion variable "CASH" is negative and statistically significant at a $1 \%$ level, but "LEV" is not statistically significant.

Regarding the variables that we are interested in, the coefficients of CONCENTRATION-5 are positive and statistically significant at a $1 \%$ level in columns (1) and (2). Meanwhile, the interaction variable CONCENTRATION-5 $\times$ INCLUSION, in columns (1) and (2), is significantly negative. The findings are consistent with the baseline estimation and confirm its robustness.

\section{[Insert Table 6 here]}

(3) Sample dependence

To test the sample's dependence, we examine whether the impact of bank concentration and financial inclusion depends on some specific firm characteristics (i.e., firm size, age, and state status), and the results are presented in Table 7. Generally, bank concentration has a positive effect on firm finance probability and finance size; however, it is diminished by the degree of financial inclusion. The results are consistent with those of the main analysis. We also find that bank concentration affects firm finance probability and finance size positively, notably when 
financial inclusion is low. The findings further demonstrate the conclusion made in the primary analysis. The analysis is explained below.

\section{[Insert Table 7 here]}

First, we include a dummy variable for firm size (SIZE): zero if the firm's assets are smaller than the median, and one if the firm's assets are larger than the median. Second, a dummy variable is included as one if the firm is older than the median firm age in our samples (AGE), and zero otherwise. Third, we explore the effect of the nature of firm ownership (STATE): one if part (or all) of the firm is owned by the State, and zero otherwise. In column (2) of Table 7, we find that the impact of bank concentration on firm finance size depends on the size of the firm, and the interaction term of SIZE with concentration is positive and statistically significant at a $1 \%$ level. This result suggests that large firms can get more credit in a high bank concentration market compared to small firms. For an accurate estimation, we find that when SIZE equals one, CONCENTRATION has a positive effect on firm finance probability for levels of INCLUSION below $0.642((0.143+0.133) / 0.430$. In contrast, when SIZE equals zero, this threshold is lower, at $0.332(0.143 / 0.430)$. This result suggests that large firms would benefit from bank concentration when the level of financial inclusion is lower.

In columns (3) and (4) of Table 7, the impact of bank concentration on firm finance probability and size depends on the age of the firm, and the interaction terms of AGE with concentration are positive and statistically significant at $5 \%$ and $1 \%$, respectively, which means long-established companies also have benefited from bank concentration more than young firms. When AGE equals one, CONCENTRATION has a positive impact on firm finance probability and firm finance size for levels of INCLUSION below $0.978((4.625+1.523) / 6.287)$ and $0.642((0.151+0.147) / 0.464)$; whereas when AGE equals zero, INCLUSION has a positive influence on firm finance probability and firm finance size before bank concentration reaches 
$0.735(4.625 / 6.278)$ and $0.325(0.151 / 0.464)$. The result indicates that long-established companies can obtain credit more easily when the degree of bank concentration increases.

Meanwhile, the interaction term of AGE with INCLUSION positively affect firm finance size and is statistically significant at a $1 \%$ level, which means long-established companies seem to have benefited from financial inclusion more than young firms. When AGE equals one, INCLUSION has a positive impact on firm finance probability and firm finance size for levels of CONCENTRATION below 34.9\% ((0.133+0.029)/0.464), while when AGE equals zero, INCLUSION has a positive effect on finance size before bank concentration reaches $28.7 \%$ $(0.133 / 0.464)$. The result reveals that long-established companies can more easily obtain credit when the degree of financial inclusion increases.

Finally, we find that the STATE variable is positive in columns (5) and (6) of Table 7, but it negatively affects bank concentration to boost finance probability and finance size. When STATE equals one, CONCENTRATION has a positive impact on firm finance probability and firm finance size for levels of INCLUSION below $0.606((7.505-3.971) / 5.829)$ and 0.334 $((0.237-0.102) / 0.403)$, while when STATE equals zero, INCLUSION has a positive influence on firm finance probability and firm finance size before bank concentration reaches $1.287^{8}$ (7.505/5.829) and $0.588(0.237 / 0.403)$. The finding suggests that state-owned enterprises can easily obtain credit. Nevertheless, the benefit decreases with increases in bank concentration.

4.2. The impacts of bank concentration and financial inclusion linking to regional credit level

\footnotetext{
${ }^{8}$ That means bank concentration always has a positive impact on firm finance probability because the turning point is above 1.
} 
The baseline results in the last subsection show that bank concentration and financial inclusion affect the listed SMEs finance probability and finance size. However, SMEs access to finance can also be influenced by other factors. Recent studies show that in emerging countries, the regional credit environment can affect SMEs access to credit and performance (e.g. Chauvet and Jacolin, 2017). In this subsection, we extend our analysis by investigating how bank concentration and financial inclusion affect SMEs' access to finance relating to the region's credit level.

Unlike an individual SME's financing availability, which might be largely dependent on the firm's characteristics and risk level, the regional/provincial credit environment acts a function that represents the region/province's financial development. We measure the regional credit environment at the provincial level. Using standard measures, we construct a regional credit environment, AVERAGE FINANCE PROBABILITY as the share of firms in province $j$ that have a bank loan, and AVERAGE FINANCE SIZE as the average loan ratio of firms in province $j$. We intend to capture the distribution of credit at the provincial level among the firms in the province.

The results reported in Table 8 show the likelihood of accessing a loan, and the size of the average loan increases with the level of bank concentration. The estimation results suggest that the degree of bank concentration in a given province affects finance probability and finance size of the firms in the region. Moreover, the impact of bank concentration on regional finance probability and finance size are also diminished by financial inclusion, which suggests that bank concentration is conducive to a better regional credit environment only in the markets with low financial inclusion. From Table 8, we can see that when financial inclusion is lower than 0.78 (or 0.55 ), bank concentration has a positive effect on regional access to a loan (or regional loan size). 
[Insert Table 8 here]

On the other hand, financial inclusion also has positive effects on finance probability and finance size for firms in a given province. As with the negative coefficient of the interaction term between financial inclusion and bank concentration, financial inclusion has positive effects on regional access to a loan (or regional loan size) for levels of bank concentration lower than $36 \%$ (or $31 \%$ ). The findings suggest that bank concentration and financial inclusion also play substitution effects for improving regional credit environment. The results are consistent with those observed in the previous subsection, which indicates that bank concentration and financial inclusion affect SME financing availability through improving the regional credit environment.

\section{Conclusion}

The promotion of financial inclusion in China in the last 15 years involves many smaller and non-state-owned financial institutions entering the lending market and competing with large and state-owned banks. Thus, the traditional bank concentration, which is unfavourable for SMEs to secure access to bank loans, is expected to respond accordingly. To answer the three research questions: (1) whether and to what extent the new bank concentration has improved the difficulty of SME financing since promoting financial inclusion; (2) how and to what extent financial inclusion policy and approaches have helped SMEs in accessing finance products and services; and (3) what is the relationship between bank concentration and financial inclusion, this study collects data from 1,509 listed SMEs in 30 provinces of China spanning 2007 and 2017, conducts rigorous analyses, and finds convincing answers.

In respect of the first question, we find that new bank concentration has positively and significantly affected the sample SME debt finance in the environment of financial inclusion. 
There are around $70 \%$ of sample firms obtaining bank loans, indicating that the promotion of financial inclusion has dramatically improved SME credit availability from bank concentration in China; however, variations in different regions exist. With respect to the second question, the results suggest that financial inclusion has played positive and significant roles in enhancing SME debt financing (about 62\% of sample firms benefit from financial inclusion despite discrepancies across regions). As regards the third question, the results from the interaction variable (CONCENTRATION $\mathrm{x}$ INCLUSION) reveal several interesting findings. For example, bank concentration is suitable for SME financing particularly in regions with a lower degree of financial inclusion; the positive effects of financial inclusion on SME credit availabilities are strengthened in the regions with lower bank concentration. The results suggest that new bank concentration and financial inclusion in China are substitutes for each other to some extent. This finding is a strong indication of the remarkable progress that has been made in widening financial inclusion in China.

Furthermore, this paper also explores other related issues and reports significant findings. We find state-owned, larger, and long-established firms still benefit more from new bank concentration and financial inclusion compared to their private, smaller, and more recently established counterparts. This finding perhaps indicates that, despite outstanding progress, financial inclusion is still a long way from satisfying the needs of vulnerable groups such as SMEs. We also find that the regional development level does not have a strong connection to SME financing, but that a regional credit level does. Specifically, bank concentration and financial inclusion influence SME financing by means of an improved regional credit environment.

To the best of our knowledge, this is the first study examining the impact of financial inclusion on the relationship between bank concentration and SME financing. Therefore, we are unable to compare our results with others. However, we can discuss our findings relating 
to the effect of bank concentration on firms' financing with that in relevant studies. For example, large scale research conducted by Beck et al. (2004) in 74 countries reveals that bank concentration obstructs firms with different sizes in obtaining finance only in countries having low levels of economic and institutional development. The findings of Beck and DemirgucKunt (2006) from reviewing substantial empirical articles also confirm that the level of financial and institutional development is vital for SMEs' growth and access to external finance. The promotion of financial inclusion is an important component of financial and institutional setting, and therefore our results echo the findings of Beck et al. (2004) and Beck and Demirguc-Kunt (2006). We further provide robust evidence that a supportive institutional environment of financial inclusion for SME financing is through the increase of banking market competition, diversity of financial product providers, and diversification of innovative and technological banking services. Another two profound studies are Love and Pería (2014) and Ryan et al. (2014), and both are large size of international surveys with multi-year data. Their findings support Market Power theory with the confirmation that a low competitive banking market constrains the accessibility of SME debt financing and requires a more diversified banking structure to reduce the dependency of large banks. Our results are consistent with theirs in principle, but furthermore indicates that financial inclusion is one of the available and effective strategies to increase bank competitions and decrease SMEs' dependency on large banks. However, our research evidence limits in one country (China). A U.S. data analysis (Han et al., 2017) suggests that both Market Power and Information theories are relevant in the explanation of the relationship between bank concentration and SME financing. In a concentrated banking market, SMEs are restricted in obtaining bank loans; however, they can still gain from a long-run relationship with banks. Compared to Han et al. (2017), our study takes a novel perspective (financial inclusion) and adds new explanations to the two theories. We will explain this point as our theoretical contributions below. 
This paper makes theoretical and empirical contributions to this under-researched area. We have added new explanations to the Market Power and Information Theories. We argue that when the banking market structure changed, with many more financial institutions engaging in competition because of the promotion of financial inclusion, large banks were compelled to enter the race. Their advantages in finance and human resources, operational and management systems, and risk control can make positive and significant contributions to SME financing. In short, a dynamic and diversified bank concentration with the healthy competition will benefit SME debt financing. Concerning the Information Theory, we argue that rapid development of new technologies and their applications in the banking sector, e.g. online banking, mobile payment (Oni et al., 2016; Bradley and Loane, 2017), have significantly increased the availability of different types of financial products and decreased the running costs of the industry. The participation of banks, other financial institutions and FinTech firms improves the provision of finance to financially vulnerable firms such as SMEs. We argue that the promotion of financial inclusion is a powerful external stimulant for revolutionising banking structure and services and supporting SME financing. Empirically, our study has provided convincing evidence endorsing our arguments. The results also reveal other meaningful findings, as discussed earlier.

Our research findings have three policy implications. First, the remarkable achievement from the financial inclusion promotion has been confirmed. The Chinese government should thus continue its strategies and approaches for the encouragement of diversity and competition in banking market and lending services. Second, as we observed, since small and private firms still face difficulties in gaining access to loans in comparison to large firms, arguably the government should consider strengthening their policies to support these vulnerable firms and narrow the gap. Third, from the evidence of regional imbalance in the development of financial inclusion, the government needs to conduct more policy research to inform the development of 
differential regional policies and approaches. Additionally, the findings of our study have relevance to other transitional economies whose banking markets were dominated by stateowned banks in the past, and are currently in the implementation phase of financial inclusion; for example, some former communist countries in Southeast Asia (Vietnam, Laos, etc.) and Eastern Europe (Romania, Bulgaria, etc.).

We also acknowledge some limitations associated with the study. The primary consideration relates to how closely our sample is representative of the underlying population. Our focus is SMEs' access to finance. Thus, ideally, the sample should represent the general population of SMEs rather than listed firms, which are at the upper end of the population. However, data accessibility and availability limit our choice. Therefore, caution should be exercised when applying the results to the entire population of SMEs. Moreover, the future research trajectory should take into account the development of FinTech companies and digital finance technologies and their influence financial inclusion, because they are developing rapidly and are likely to have a significant impact on banking market structure and lending technologies in the future.

\section{References}

Acharya, V. and Xu, Z. (2017), "Financial dependence and innovation: The case of public versus private firms", Journal of Financial Economics, Vol.124 No.2, pp.223-243.

Beck, T. and Demirgüç-Kunt, A. (2006), "Small and medium-size enterprises: Access to finance as a growth constraint", Journal of Banking \& Finance, Vol.30 No.11, pp.29312943.

Beck, T. and Demirgüç-Kunt, A. (2008), "Access to finance: An unfinished agenda", The World Bank Economic Review, Vol. 22 No.3, pp.383-396.

Beck, T., Demirgüç-Kunt, A. and Maksimovic, V. (2004), "Bank competition and access to finance: International evidence", Journal of Money, Credit and Banking, Vol.36 No.5, pp.627-648.

Beck, T., Demirguc-Kunt, A. and Pería, M. (2005a), "Reaching out: Access to and use of banking services across countries”, Journal of Financial Economics, Vol. 85 No.1, pp.234-266 
Beck, T., Demirguc-Kunt, A. and Levine R. (2005b) "SMEs, growth, and poverty: Crosscountry evidence," Journal of Economic Growth, Vol. 10 No.3, pp.199-229.

Berger, A.N. and Udell, G.F. (1998), "The economics of small business finance: The role of private equity and debt markets in the finance growth cycle", Journal of Banking \& Finance, Vol.22 No.6-8, pp.613-673.

Berger, A. N. and Udell, G. F. (2002). "Small business credit availability and relationship lending: The importance of bank organisational structure", The Economic Journal, Vol.112 No.4, pp. 32-53.

Binks, M., Ennew, C. and Mowlah, A. (2006), "The relationship between private businesses and their banks", International Journal of Bank Marketing, Vol. 24 No. 5, pp. 346-355.

Bradley, L. and Loane, S. (2017). "Bank adoption of mobile banking: stakeholder perspective", International Journal of Bank Marketing, Vol.35 No.7, pp.1152-1172.

CBRC (2016) China Banking Regulatory Commission 2016 Annual Report.

CGAP (2015), Digital Financial Inclusion: Implications for Customers, Regulators, Supervisors, and Standard-Setting Bodies. CGAP Brief. https://www.cgap.org/sites/default/files/researches/documents/Brief-Digital-FinancialInclusion-Feb-2015.pdf

Chauvet, L. and Jacolin, L. (2017). "Financial inclusion, bank concentration, and firm performance", World Development, Vol.97 September, pp.1-13.

Degryse, H. and Ongena, S. (2005), "Distance, lending relationships and competition", The Journal of Finance, Vol.60 No.1, pp.231-266.

Du, J., Bian, C. and Gan, C. (2017). "Bank competition, government intervention and SME debt financing", China Finance Review International, Vol.7 No.4, pp.478-492.

García-Teruel, P.J. and Martínez-Solano, P. (2008). "On the determinants of SME cash holdings: Evidence from Spain", Journal of Business Finance \& Accounting, Vol.35 No.1-2, pp.127-149.

Goldsmith, R.W. (1969), Financial Structure and Development. Yale University Press: New Haven CT.

Han, L., Zhang, S. and Greene, F. J. (2017), "Bank market concentration, relationship banking, and small business liquidity", International Small Business Journal, Vol.35 No.4, pp.365384.

Harrison, A. E., Lin, J. Y. and Xu, L. C. (2014). "Explaining Africa's (dis) advantage”, World Development, Vol.63 November, pp.59-77.

Heckman, J.J. (1979), “Sample selection bias as a specification error”, Econometrica, Vol.47 No.1, pp.153-161.

Klein, M. A. (1971), "A theory of the banking firm”, Journal of Money, Credit and Banking, Vol.3 No.2, pp.205-218. 
Koku, P. S. (2015), "Financial exclusion of the poor: a literature review", International Journal of Bank Marketing, Vol.33 No.5, pp.654-668.

Leon, F. (2015), "Does bank competition alleviate credit constraints in developing countries?" Journal of Banking \& Finance. Vol.57 August, pp.130-142.

Li, Y., Meng, X. and Wei, X. (2015), "China's new third board market: Opportunities and challenges", Procedia Computer Science, Vol.55, pp.1050-1059.

Li, H., Wu, J., Lu, Z. (2020), "Bank diversity and SME innovation: Evidence from China", International Journal of Bank Marketing, Vol. 38 No. 2, pp. 265-282.

Liu, P., Huang, S. and Li, H. (2018), "Bank concentration and firms' debt structure: Evidence from China”, Annals of Economics and Finance, Vol.19 No.1, pp.213-227.

Love, I. and Pería, M.S. (2014), "How bank competition affects firms' access to finance", The World Bank Economic Review, Vol.29 No.3, pp.413 - 448.

Oni, A. A., Adewoye, O. J. and Eweoya, I. O. (2016). "E-banking users' behaviour: e-service quality, attitude, and customer satisfaction", International Journal of Bank Marketing, Vol.34 No.3, pp.347-367.

Petersen, M.A. and Rajan, R.G. (1994), "The benefits of lending relationships: Evidence from small business data", The Journal of Finance, Vol.49 No.1, pp.3-37.

Petersen, M.A. and Rajan, R.G. (1995), "The effect of credit market competition on lending relationships", The Quarterly Journal of Economics, Vol.110 No.2, pp.407-443.

Rajan, R. and Zingales, L. (1998), "Financial development and growth", American Economic Review, Vol.88 No.3, pp.559-586.

Rice, T., Strahan, P.E. (2010), "Does credit competition affect small-firm finance?", The Journal of Finance, Vol.65 No.3, pp.861-889.

Ryan, R. M., O’Toole, C. M. and McCann, F. (2014), "Does bank market power affect SME financing constraints”, Journal of Banking \& Finance, Vol.49 December, pp.495-505.

Sarma, M. and Pais, J. (2011), "Financial inclusion and development", Journal of International Development, Vol.23 No.5, pp.613-628.

World Bank. (2013). “Global Financial Development Report 2013”, World Bank Group.

World Bank. (2014). “Global Financial Development Report 2014”. World Bank Group.

Wu, J., Song, J. and Zeng, C. (2008), “An Empirical Evidence of Small Business Financing in China”, Management Research News, Vol. 31 No.12, pp.959-975.

Zhou, G., Gong, K., Luo, S. and Xu, G. (2018), "Inclusive finance, human capital and regional economic growth in China”, Sustainability, Vol.10 No.4, pp.1194-1214. 